\title{
Maintenance of human epididymal epithelial cell function in monolayer culture
}

\author{
T. G. Cooper, C. H. Yeung, R. Meyer and H. Schulze* \\ Institute of Reproductive Medicine, University of Münster, Steinfurter Straße 107, \\ D-4400 Münster; and *Urology Clinic, Ruhr University of Bochum, Postfach 1469 , \\ D-4690 Herne 1, Federal Republic of Germany
}

\begin{abstract}
Summary. Cells liberated by enzyme treatment of tubules dissected out of human epididymides obtained at castration for prostatic carcinoma were cultured for up to 42 days on permeable supports. Outgrowth and monolayer formation was unrelated to the age of the patient or his treatment with anti-androgens. The cells comprising the monolayer were cuboidal and shorter than those in situ but their ultrastructure was characteristic of epithelial cells. There was no evidence of smooth muscle cells or fibroblast overgrowth. The cells manifested fluid-phase and adsorptive endocytosis from both apical and baso-lateral aspects and released into the medium alkaline and acid phosphatases and $\mathrm{N}$-acetylglucosaminidase.
\end{abstract}

Keywords: man, epididymis; cell culture; ultrastructure; endocytosis; secretion

\section{Introduction}

Study of the physiology of exocrine organs has received a major stimulus with the advent of permeable supports for monolayer culture. In addition to the benefits conferred by culture of known cell types and economy of limited tissue, the specific function of the epithelium, directional secretion, can now be monitored. Such systems have been applied to the male reproductive tract, including demonstrations of endocytosis, ion transport and vectorial secretion by epithelial cells from the rat efferent ducts (Byers et al., 1985), caput and corpus epididymidis (Byers et al., 1986; Cooper et al., 1989) and cauda epididymidis (Cuthbert \& Wong, 1986; Cooper et al., 1989). As an organ responsible for preparing spermatozoa for fertilization (see Cooper, 1986) knowledge of human epididymal function may eventually help advances in the treatment of male infertility or the design of post-testicular contraceptive agents. First attempts to culture human epididymal epithelial cell monolayers culture on permeable supports are reported here.

\section{Materials and Methods}

Material. Human epididymides were obtained over a 3-year period from 39 men (mean age 74 years, range $59-83$ years) at castration operations for prostatic carcinoma. Of the 14 tissues from which culture was attempted, 7 came from men who had received antiandrogen treatment before the operation, and 5 were known not to have received any treatment (Table 1). Tissues were transported in Ham's F-12 Medium on ice and brought to the laboratory within $90 \mathrm{~min}$. Motile spermatozoa were found in 6 of these epididymides after mincing the tissue (Table 1).

Culture media and culture inserts. The media for enzyme addition (containing antibiotics and fungicide: ABF) and culture (serum-free defined medium containing D-valine: SFDM) and the preparation of culture inserts were as described by Cooper et al. (1989) for the culture of rat epididymal cells. Both Ham's F-12 and Williams' Medium E containing D-valine (Gibco Europe GmbH, Karlsruhe, FRG) were used for SFDM. From the time of arrival at the laboratory the tissue was kept in sterile conditions in a vertical laminar flow hood (TC72: Flow Labs GmbH, Meckenheim, FRG). 

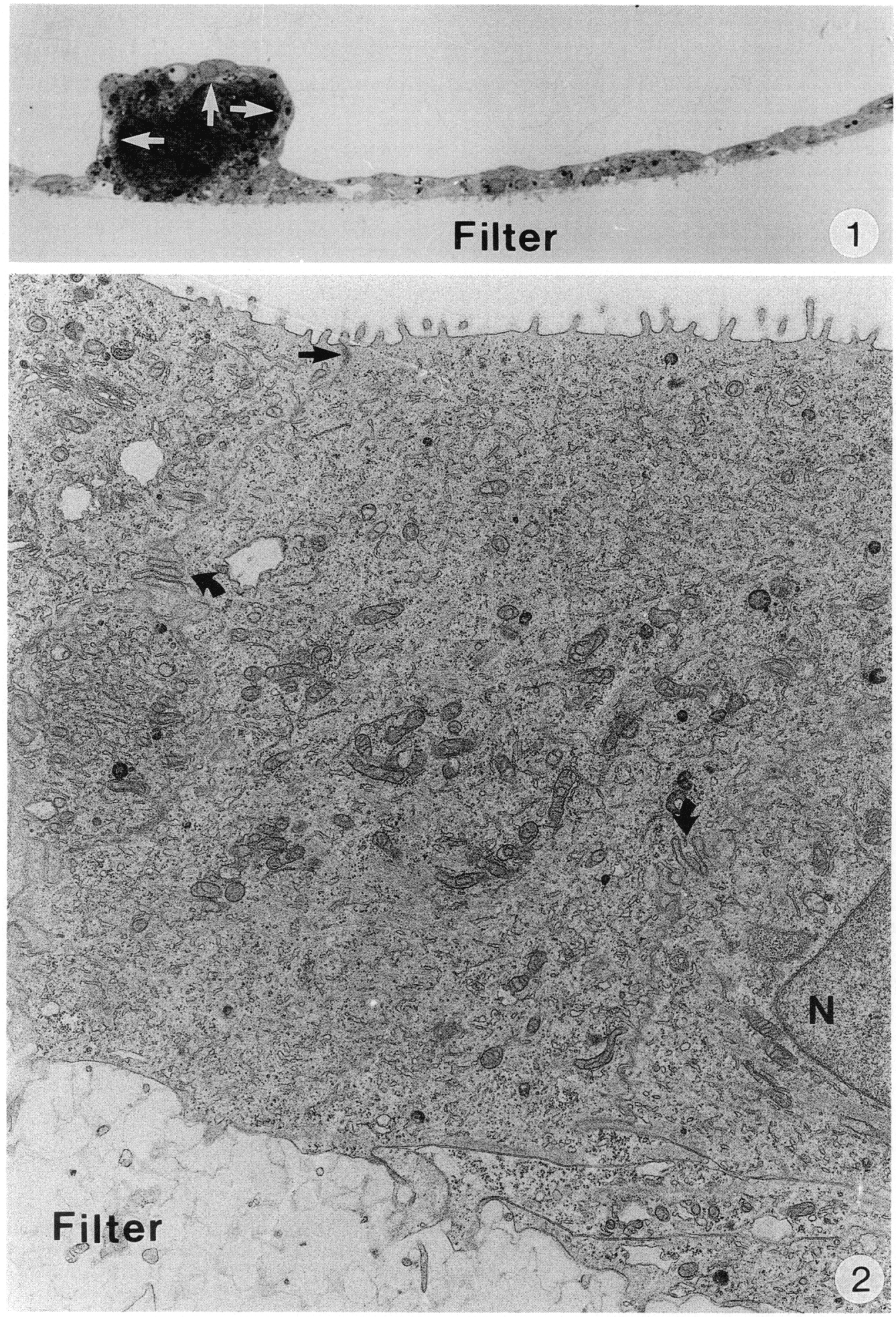
Details of culture. Initial attempts at culture were made with the technique described for rat cultures (Cooper $e t$ al., 1989). The large amount of connective tissue in the human organ, however, rendered this fruitless; epithelial fragments released by enzymic digestion adhered to the connective tissue and were either prevented from attaching to the filter by it or were removed with it. Digestion with proteases did not help. The method finally adopted made use of the observations of Lopez \& Breucker (1986) that the human epididymis contains much elastic tissue. It was more difficult to prepare tissue from the caput and cauda epididymidis and these regions were not cultured. The corpus epididymidis was dissected from the rest of the organ and the connective tissue capsule was removed with fine forceps to the extent that was possible without tearing the tubules. Tubule loops were freed similarly. The tissue was added to filter-sterile collagenase $(24000 \mathrm{U})$ and elastase $(38400 \mathrm{mU})$ in $12.5 \mathrm{ml} \mathrm{ABF}$ in a sterile beaker and shaken at 40 strokes per min at $37^{\circ} \mathrm{C}$ for $15-20 \mathrm{~min}$. At this time the contents of the beaker were transferred into a Petri dish and the connective tissue septa were gently dissected from the tubule loops by hand with fine forceps and scissors. Viewing the dish against a dark background facilitated separation of the whitish connective tissue from the more yellowish tubules. Tissues were replaced in the beaker for further digestion and this process was repeated twice. The collagenase/elastase medium was then replaced by a fresh preparation, and mixing, dissection and unravelling of tubule segments were continued as before until fairly clean epididymal tubules could be isolated. The tubules were minced with fine scissors and transferred to $50 \mathrm{ml}$ tubes, mixed and allowed to settle for $60 \mathrm{sec}$. The supernatant was recovered, centrifuged at $130 \mathrm{~g}$ for $5 \mathrm{~min}$ and the pellet (referred to as Fragments 1) was washed with ABF. The settled tubules were incubated with filtersterile collagenase $(24000 \mathrm{U})$ and hyaluronidase $(3125 \mathrm{U})$ in $12.5 \mathrm{ml} \mathrm{ABF}$ for $20 \mathrm{~min}$ at $37^{\circ} \mathrm{C}$. After mixing and settling the supernatant was harvested as above (Fragments 2) and the undigested tubule pellet was incubated with the fragment-free enzyme supernatant for a further $20 \mathrm{~min}$. Repetition of this procedure with fresh collagenase and hyaluronidase resulted in the accumulation of several washed "Fragments" containing free cells and small epithelial fragments. All were pooled, centrifuged at $130 \mathrm{~g}$ for $5 \mathrm{~min}$ and washed sequentially with $20 \mathrm{ml} \mathrm{ABF}, 10 \mathrm{ml}$ D-valine medium and $10 \mathrm{ml}$ SFDM before addition of cell fragments to culture inserts as described by Cooper et al. (1989). Cell counts were not made but the number of fragments added to the filter inserts, as judged from the turbidity of the fragment suspension, was estimated to be similar to that (around $10^{6}$ cells) added for the rat.

Assays. Acid and alkaline phosphatase and $\mathrm{N}$-acetyl-glucosaminidase were assayed as described by Cooper $e t$ al. (1989).

Morphology of the cultured cells. Fixation of cells for light and electron microscopy and measurement of cell heights with the aid of a digitising tablet on $1 \mu \mathrm{m}$ sections were as previously described (Yeung et al., 1989a). The extent of cover of the filter was estimated subjectively from haematoxylin-stained filters.

Experiments on endocytosis. After changing medium the monolayers were incubated with SFDM containing either horseradish peroxidase (HRP: $0.2 \mathrm{mg} / \mathrm{ml}$ ), native ferritin (NF: $1-10 \mathrm{mg} / \mathrm{ml}$ ) or cationic ferritin (CF: $1 \mathrm{mg} / \mathrm{ml}$ ) added to the apical or basal compartment for $20 \mathrm{~min}$ to $17 \mathrm{~h}$ at $34^{\circ} \mathrm{C}$ (see Table 2). Tissues were then processed for light and electron microscopy as above and examined in a Philips 300 electron microscope.

\section{Results}

\section{Growth of monolayers}

Once the method of tissue preparation had been established 9 successful cultures resulted from 14 patients (see Table 1). Fragments remained apparently inactive for the 1 st or 2 nd weeks before attachment and spreading of the cells was noticed and the cells remained on the filters for periods of up to 42 days (Table 1). Various degrees of cover of the filter were achieved. For those estimated to cover at least $75 \%$ by Days $8-13$ of culture, media were then changed every day and sequential measurements of secreted enzymes were made. In two cultures $(\mathrm{H} 26, \mathrm{H} 27)$ an apparent complete cover of the filter was achieved on Days 36 and 42, respectively. Cell heights varied between cultures (see Table 3 ) and were lower than for epithelial cells initially present in the corpus epididymidis (23-38 $\mu \mathrm{m}$, obtained from semi-thin sections of whole tubules from glutaraldehyde-fixed material). There was no change in cell heights with time in culture.

Fig. 1. Light micrograph of human epididymal epithelium (H30) cultured for 13 days. A low epithelium (arrows) has grown over the underlying fragment and forms a monolayer on the filter. $\times 270$.

Fig. 2. An electron micrograph of a human epididymal epithelial cell (H30) grown for 22 days in culture. An intercellular junction (straight arrow) and interdigitating connections (curved arrows) between cells are shown. $\mathrm{N}$ denotes nucleus. $\times 7560$. 

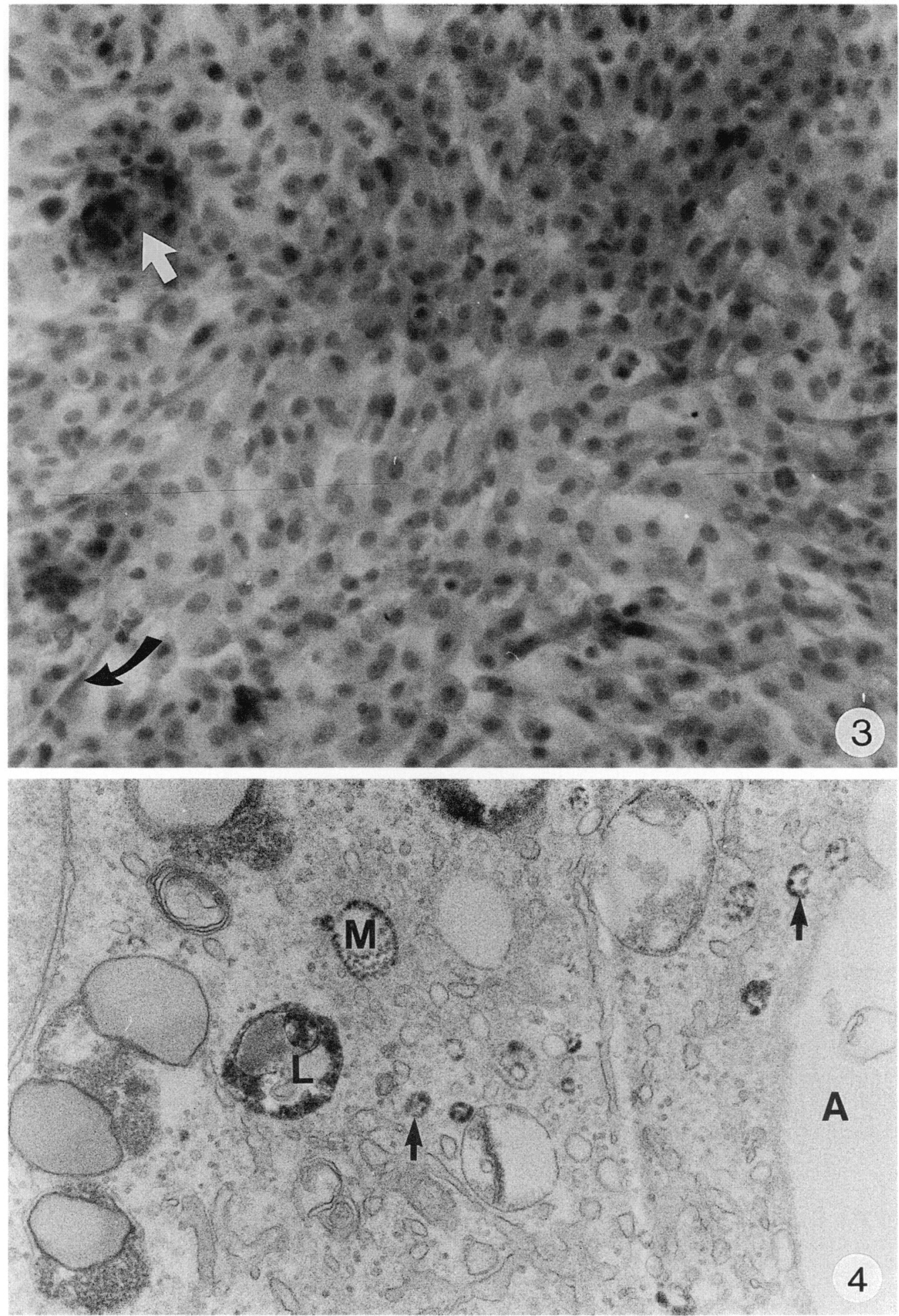
Table 1. Patients from whom epididymal tissue was processed for culture

\begin{tabular}{|c|c|c|c|c|c|}
\hline Culture & $\begin{array}{l}\text { Age of } \\
\text { patient } \\
\text { (years) }\end{array}$ & $\begin{array}{c}\text { Antiandrogen } \\
\text { therapy* }\end{array}$ & $\begin{array}{c}\text { Motile } \\
\text { spermatozoa } \\
\text { confirmed }\end{array}$ & $\begin{array}{l}\text { No. of } \\
\text { chambers }\end{array}$ & $\begin{array}{l}\text { Days } \\
\text { cultured }\end{array}$ \\
\hline H21 & 74 & $50 \mathrm{mg}$ CPA p.o., 4 days & Yes & 4 & 19 \\
\hline $\mathrm{H} 22$ & 78 & Not known & No & 10 & 18 \\
\hline $\mathrm{H} 23$ & 73 & $300 \mathrm{mg}$ CPA i.m. & Yes & No growth & \\
\hline $\mathrm{H} 24$ & 69 & None & No & No growth & \\
\hline $\mathrm{H} 25$ & 73 & Not known & No & 3 & 28 \\
\hline $\mathrm{H} 26$ & 76 & $300 \mathrm{mg}$ CPA i.m. & Yes & 3 & 36 \\
\hline $\mathrm{H} 27$ & 64 & None & Yes & 5 & 42 \\
\hline $\mathrm{H} 28$ & 70 & 300 mg CPA i.m. & Yes & Little growth & \\
\hline $\mathrm{H} 29$ & 80 & $50 \mathrm{mg}$ CPA p.o., 12 days & No & Little growth & \\
\hline $\mathrm{H} 30$ & 60 & $50 \mathrm{mg}$ CPA p.o., 10 days & No & 8 & 35 \\
\hline H3I & 70 & $50 \mathrm{mg}$ CPA p.o., 1 day & No & 10 & 23 \\
\hline $\mathrm{H} 32$ & 79 & None & No & 3 & 22 \\
\hline $\mathrm{H} 33$ & 84 & None & No & 5 & 27 \\
\hline H34 & 72 & None & Yes & No growth & \\
\hline
\end{tabular}

${ }^{*} \mathrm{CPA}$, cyproterone acetate (Androcur); p.o., per os; i.m., intramuscularly.

Table 2. Location of endocytic markers in cultured human epididymal epithelium

\begin{tabular}{|c|c|c|c|c|c|c|c|c|c|c|}
\hline \multirow[b]{2}{*}{ Culture } & \multirow{2}{*}{$\begin{array}{c}\text { Age } \\
\text { (days) }\end{array}$} & \multirow{2}{*}{$\begin{array}{l}\text { Marker* } \\
(\mathrm{mg} / \mathrm{ml})\end{array}$} & \multirow{2}{*}{$\begin{array}{l}\text { Incubation } \\
\text { time }\end{array}$} & \multirow{2}{*}{$\begin{array}{l}\text { Application } \\
\text { site }\end{array}$} & \multicolumn{6}{|c|}{ Labelled structures $\dagger$} \\
\hline & & & & & ICS & $\mathrm{pmB}$ & ves. & MVB & lys. & pmA \\
\hline $\mathrm{H} 27$ & 36 & $\mathrm{CF}(1)$ & $20 \mathrm{~min}$ & Apex & & & + & + & + & + \\
\hline $\mathrm{H} 30$ & 35 & CF (1) & $1 \mathrm{~h}$ & Apex & & & + & + & + & + \\
\hline $\mathrm{H} 30$ & 22 & CF (1) & $17 \mathrm{~h}$ & Base & \multicolumn{6}{|c|}{ No penetration of filter } \\
\hline $\mathrm{H} 27$ & 36 & NF (I0) & $20 \mathrm{~min}$ & Apex & \multicolumn{6}{|c|}{ No tracer visible } \\
\hline $\mathrm{H} 30$ & 13 & NF (5) & $1 \mathrm{~h}$ & Apex & \multicolumn{6}{|c|}{ No tracer visible } \\
\hline $\mathrm{H} 32$ & 22 & NF $(10)$ & $2 \mathrm{~h}$ & Apex & & & + & + & + & \\
\hline H32 & 22 & $\operatorname{HRP}(0 \cdot 5)$ & $2 \mathrm{~h}$ & Apex & & & + & + & + & \\
\hline H30 & 22 & $\operatorname{HRP}(0 \cdot 2)$ & $17 \mathrm{~h}$ & Base & + & + & + & + & + & \\
\hline
\end{tabular}

${ }^{*} \mathrm{CF}$, cationic ferritin; $\mathrm{NF}$, native ferritin; $\mathrm{HRP}$, horseradish peroxidase.

†ICS, intercellular space; pmB, basal plasma membrane; ves., vesicles; MVB, multivesicular bodies; lys., lysosomes; pmA, apical plasma membrane.

\section{Morphological characteristics}

Low cuboidal cells spread out from the epithelial fragments to form a monolayer on the filter, with some overgrowing the original fragments (Fig. 1). In two cultures an extensive network of tissue obscured the development of a cell monolayer beneath it (not shown). Most of the cells were of epithelioid shape, although interspersed between the islands of these were other, more elongated cells (Fig. 3), but these never formed an extensive overgrowth. No characteristic muscle or

Fig. 3. Light micrograph of human epididymal epithelium (H25) cultured for 19 days. Epithelioid cells covering the filter have moved away from their parent fragments (white arrow) and occasional slender cells (curved black arrow) are present. $\times 280$.

Fig. 4. Following incubation of the monolayer $(\mathrm{H} 30$, Day 22) with horseradish peroxidase (HRP) in the basal compartment for $17 \mathrm{~h}$ the enzyme is localized within lysosomes (L), multivesicular bodies (M) and vesicles (arrows) close to the apical surface (A) of the cell. $\times 33300$. 
Table 3. Cell heights of human epididymal cells in culture

\begin{tabular}{lcrrr}
\hline & \multicolumn{4}{c}{ Cell height $(\mu \mathrm{m})$} \\
\cline { 3 - 5 } Culture* & $\begin{array}{c}\text { Days } \\
\text { cultured }\end{array}$ & Mean & s.d. & $n \dagger$ \\
\hline H27 CF Apex & 36 & $7 \cdot 0$ & $2 \cdot 6$ & 400 \\
H27 NF Apex & 36 & $7 \cdot 0$ & $2 \cdot 6$ & 405 \\
H30 NF Apex & 13 & $10 \cdot 8$ & $5 \cdot 2$ & 764 \\
H30 HRP Base & 22 & $11 \cdot 2$ & $4 \cdot 7$ & 602 \\
H30 CF Base & 22 & $7 \cdot 7$ & $4 \cdot 0$ & 725 \\
H30 CF Apex & 35 & $12 \cdot 0$ & $4 \cdot 8$ & 308 \\
H32 NF Apex & 22 & $4 \cdot 7$ & $2 \cdot 2$ & 314 \\
H32 HRP Apex & 22 & $6 \cdot 4$ & $2 \cdot 5$ & 291 \\
H33 NF Apex & 19 & 3.9 & $2 \cdot 1$ & 355 \\
\hline
\end{tabular}

*Abbreviations as in legend to Table 2 .

$†$ No. of fixed points on each monolayer measured.

fibroblast like cells atached to the filters. Electron micrographs of the epithelial cells revealed short stereocilia studding the apical surface of the cells (Figs 2 \& 5) and cytoplasmic insertions projecting into the filter support (Fig. 2). Interdigitating cell junctions between cells (Fig. 2) and the normal complement of mitochondria, endoplasmic reticulum, Golgi and lysosomes were present within the cytoplasm (Figs 2, 4 \& 5).

\section{Endocytosis}

When placed in the basal compartment for $17 \mathrm{~h} \mathrm{HRP} \mathrm{was} \mathrm{found} \mathrm{at} \mathrm{the} \mathrm{base} \mathrm{of} \mathrm{the} \mathrm{epithelium}$ and between the cells but was not able to penetrate the junctional complexes (Fig. 5). Within the cell it was found in vesicles close to the apical membrane, in multivesicular bodies and in lysosomes (Fig. 4). A similar location of the tracer was observed when it was present for $2 \mathrm{~h}$ in the apical compartment, except that it did not penetrate into the intercellular spaces (not shown). Native ferritin when placed in the apical compartment required a high concentration and long period of incubation before it could be detected (albeit rarely) in cytoplasmic organelles (Fig. 8, Table 2). Cationic ferritin was unable to penetrate the culture filter even in overnight $(17 \mathrm{~h})$ incubations. When placed in the apical compartment it adhered to the apical cell surface (Fig. 6) and was found in small vesicles, or parts of the apical and lateral canaliculi system, multivesicular bodies and lysosomes within $20 \mathrm{~min}$ (Fig. 7).

\section{Secretion of enzymes}

Differences in the activity of enzymes per unit volume throughout four cultures are given in Table 4. There was always significantly higher activity of NAG in the apical compartment but differences in AKP activities between compartments were small. Estimates of total daily secretion varied between cultures. In some cultures secretion of AKP was low (H25, H26, <0.1 mU/day) whereas it rose slowly after about 1 month in culture $\mathrm{H} 27$ (Fig. 9) and fell in the first 3 weeks of $\mathrm{H} 30$ (Fig. 10). For both $\mathrm{H} 27$ and $\mathrm{H} 30$ there was apparently higher basal secretion of the enzyme. Total secretion of NAG displayed no net direction in $\mathrm{H} 30$, but in $\mathrm{H} 27$ secretion into the apical chamber exceeded that into the basal (Figs $9 \& 10$ ). When measured (H30) ACP secretion into the basal compartment increased noticeably after the 3 rd week when AKP secretion had declined to a stable secretion rate (Fig. 10). Equal activities in apical and basal chambers $(0.39 \mathrm{mU} / \mathrm{ml})$ were associated with apparent greater basal secretion (Fig. 10). 


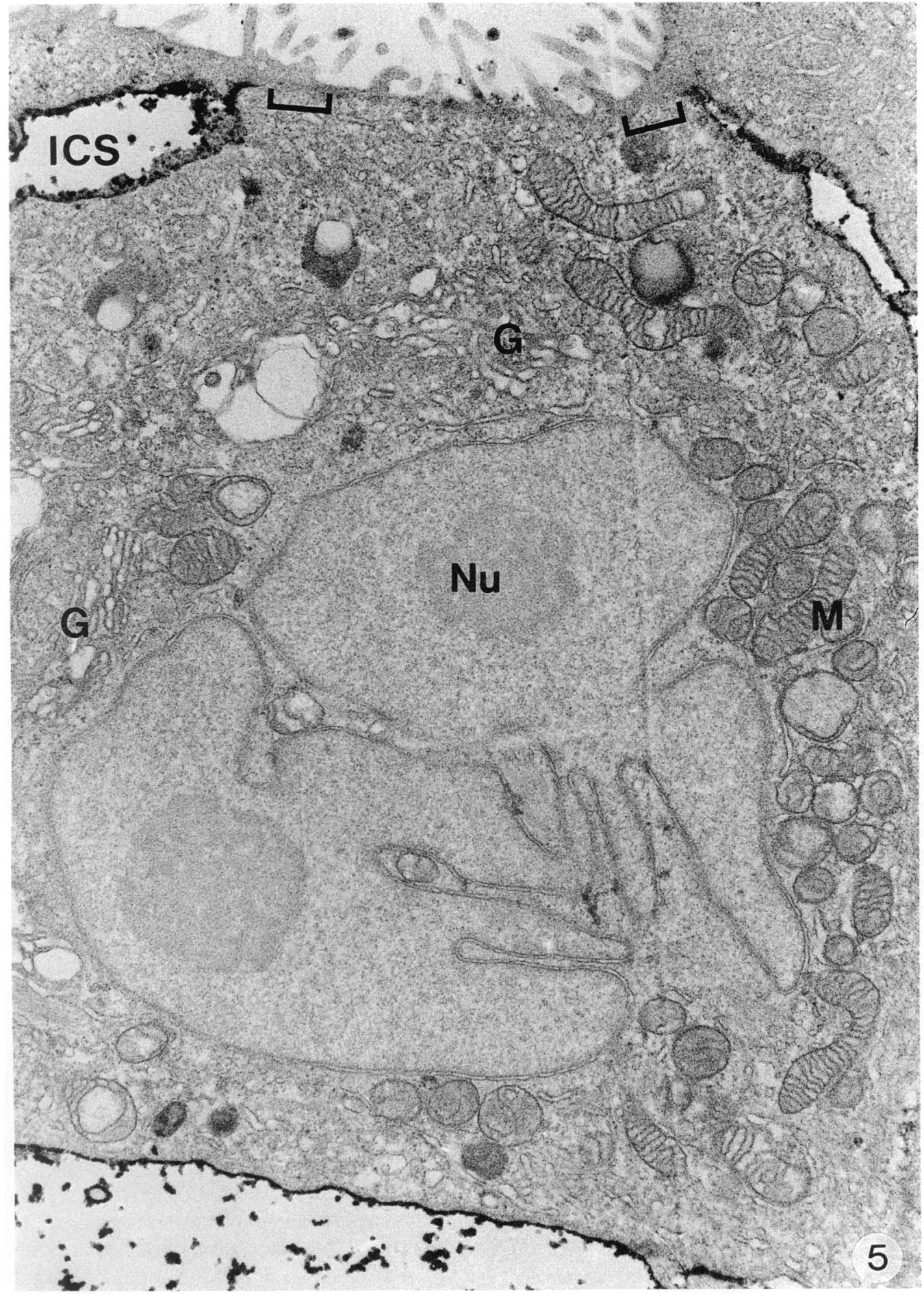

Fig. 5. Same tissue as Fig. 4. In this section the filter has come away from the basal surface of the cells during tissue processing. HRP reaction product is seen in the intercellular spaces (ICS) but is excluded from the junctional complexes (square brackets). Golgi (G), mitochondria (M) and nucleoli $(\mathrm{Nu})$ are evident. $\times 13550$. 

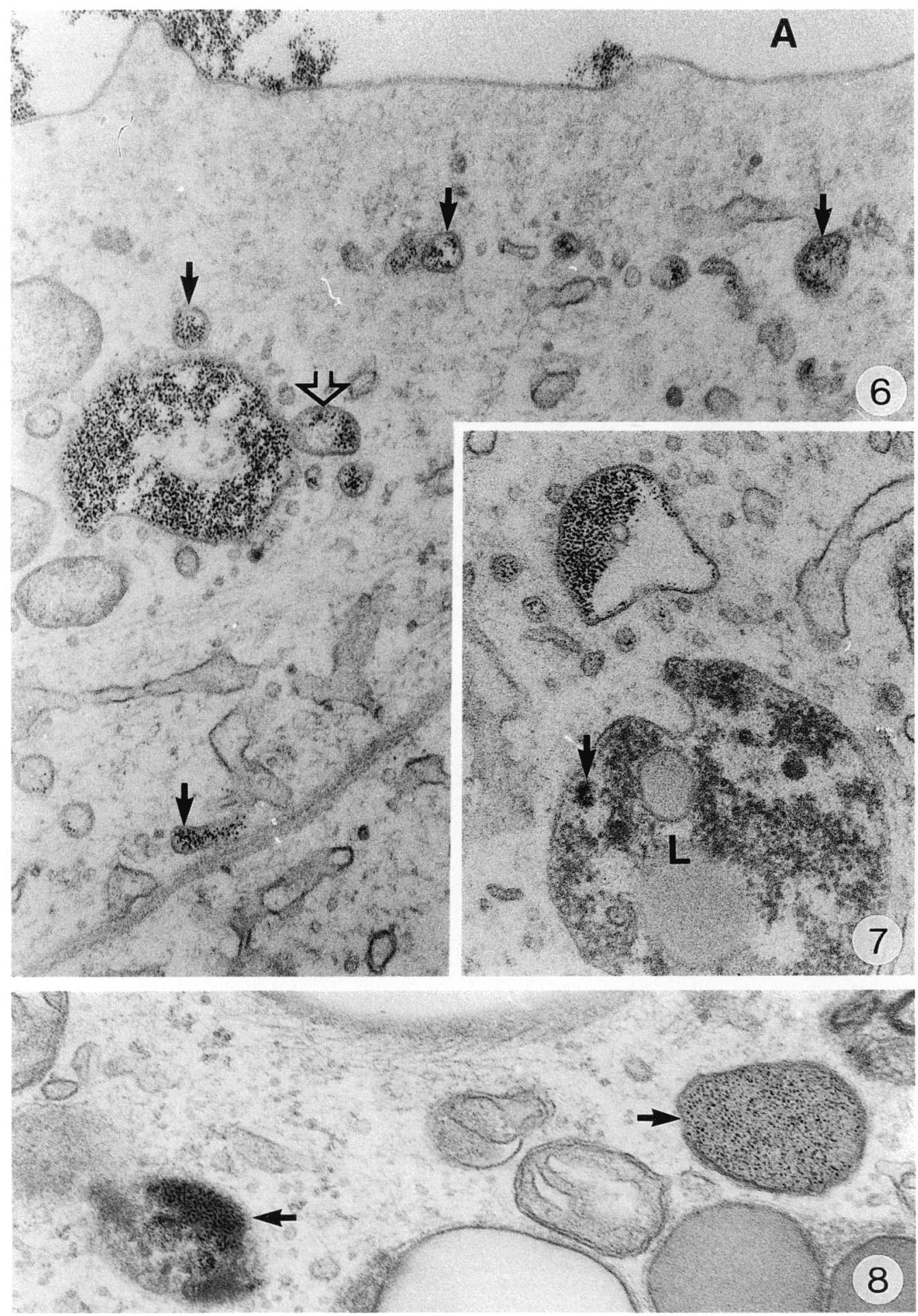
Table 4. Concentrations and apical-basal differences of alkaline phosphatase and $\mathrm{N}$ acetylglucosaminidase in spent culture medium from human epididymal epithelial cells

\begin{tabular}{|c|c|c|c|c|c|c|c|c|}
\hline \multirow[b]{2}{*}{ Culture } & \multicolumn{4}{|c|}{$\mathrm{N}$-acetylglucosaminidase } & \multicolumn{4}{|c|}{ Alkaline phosphatase } \\
\hline & No.* & Apical & Basal & Difference & No.* & Apical & Basal & Difference \\
\hline $\mathrm{H} 25$ & 26 & 0.60 & $0 \cdot 24$ & $0.36 \dagger$ & 26 & 0.09 & 0.08 & 0.01 \\
\hline $\mathrm{H} 26$ & 54 & 1.59 & 0.59 & $1.00 \dagger$ & 53 & $0 \cdot 10$ & 0.13 & $-0.02 \dagger$ \\
\hline $\mathrm{H} 27$ & 114 & 1.71 & $0 \cdot 51$ & $1 \cdot 20 \dagger$ & 117 & $0 \cdot 25$ & 0.24 & 0.01 \\
\hline $\mathrm{H} 30$ & 74 & $1 \cdot 15$ & 0.66 & $0.49 \dagger$ & 69 & 0.33 & $0 \cdot 3 \mathrm{I}$ & $0.02 \dagger$ \\
\hline
\end{tabular}

Values are the mean activities $(\mathrm{mU} / \mathrm{mi}$ ) of each enzyme in the apical and basal compartments (about $0.4 \mathrm{ml}$ and $0.6 \mathrm{ml}$, respectively) and the net apical-basal differences for the duration of the culture.

*Number of paired comparisons.

$\Varangle$ Paired $t$ test, $P<0.05$.

\section{Discussion}

Much of what is known about the functioning of the human epididymis has been derived from a tubule culture system (Tezón \& Blaquier, 1981) in which human epididymal tubules are maintained for up to 8 days. This method allows study of the whole tubule with metabolic contributions from the peritubular muscle and intraluminal spermatozoa as well as the epithelium. Cell culture systems, on the other hand, permit study of isolated cells in the absence of other cell types and growth of human fetal epididymal cells on plastic has recently been reported (Harris \& Coleman, 1989). In regard to nutrient access and the polarity of the cells, however, growth on permeable supports is superior to that on plastic (Byers et al., 1986) and it also offers the possibility of determining directional secretion and absorption and transcellular transport. In the present study cells isolated from the adult human epididymis were grown in monolayer culture on permeable supports, permitting for the first time study of isolated cells.

The preparation of epithelial fragments from the human epididymis suitable for plating proved much more difficult than with the rat. The main obstacle was the amount of connective tissue in which the tubule lies embedded. By suitable enzymic digestion and manual dissection, however, short lengths of tubule could be obtained that could be further digested. Another species difference was the time taken for the fragments to attach to the filter; from 1 to 2 weeks were required for the human, as opposed to $1-4$ days for the rat. Once human cells attached, however, they remained adherent for as much as 42 days, whereas rat cells fall off between 9 and 12 days (Cooper et al., 1989). These differences may reflect different requirements of cells for a suitable basement membrane material for attachment. The commercially available preparation used here (from a mouse sarcoma) may be more similar to that naturally found in man than rat; alternatively, there may be a species difference in the sensitivity of basement membrane receptors to the digestion procedures employed. The cells spreading from the fragments in this study appeared from their shape to be of two types: most were epithelioid cells and the rest scattered spindly cells. That the latter cells did not divide to take over the monolayer is most probably a consequence of the use of D-valine, an amino acid that cannot be converted by fibroblasts to essential L-valine (Gilbert \& Migeon, 1975). Observations with the electron microscope confirmed that neither fibroblast nor muscle cells were part of

Fig. 6. Cationic ferritin placed in the apical compartment for $1 \mathrm{~h}$ is found adhering to the plasma membrane of the cells (H30, Day 35) and within vesicles and components of the canaliculi system close to the basolateral membrane (arrows). One of these is about to fuse with a multivesicular body (open arrow). $\times 55800$.

Fig. 7. Cationic ferritin in a multivesicular body and lysosome (L) (arrow). $\times 55800$.

Fig. 8. Native ferritin within lysosomal-like bodies (arrows) in the epithelium of H32 (Day 22), $2 \mathrm{~h}$ after incubation in contact with the apical aspect of the cells. $\times 55800$. 


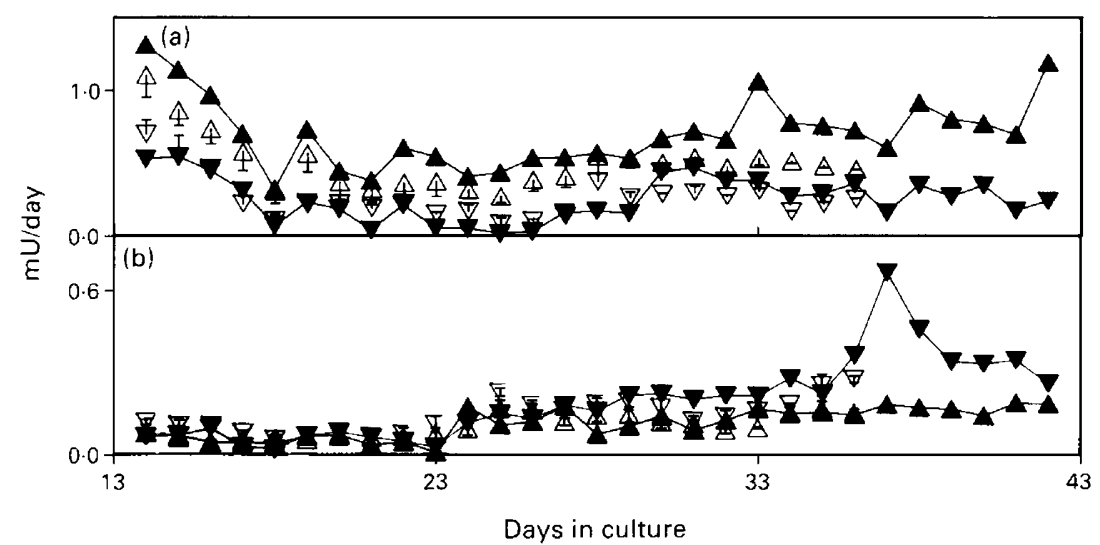

Fig. 9. Secretion of (a) $\beta$-N-acetylglucosaminidase (NAG) and (b) alkaline phosphatase (AKP) by epithelial monolayers derived from the human epididymis (H27). Daily secretion (ordinate) is plotted against time in culture (abscissa) for apically directed $(\Delta, \boldsymbol{\Delta})$, and basally directed $(\boldsymbol{\nabla}, \nabla)$ secretions. Data from one chamber are given by the closed symbols; the mean (and s.e.m.) secretion of 3-8 other chambers from the same tissue for Days 14-36 are given by the open symbols.

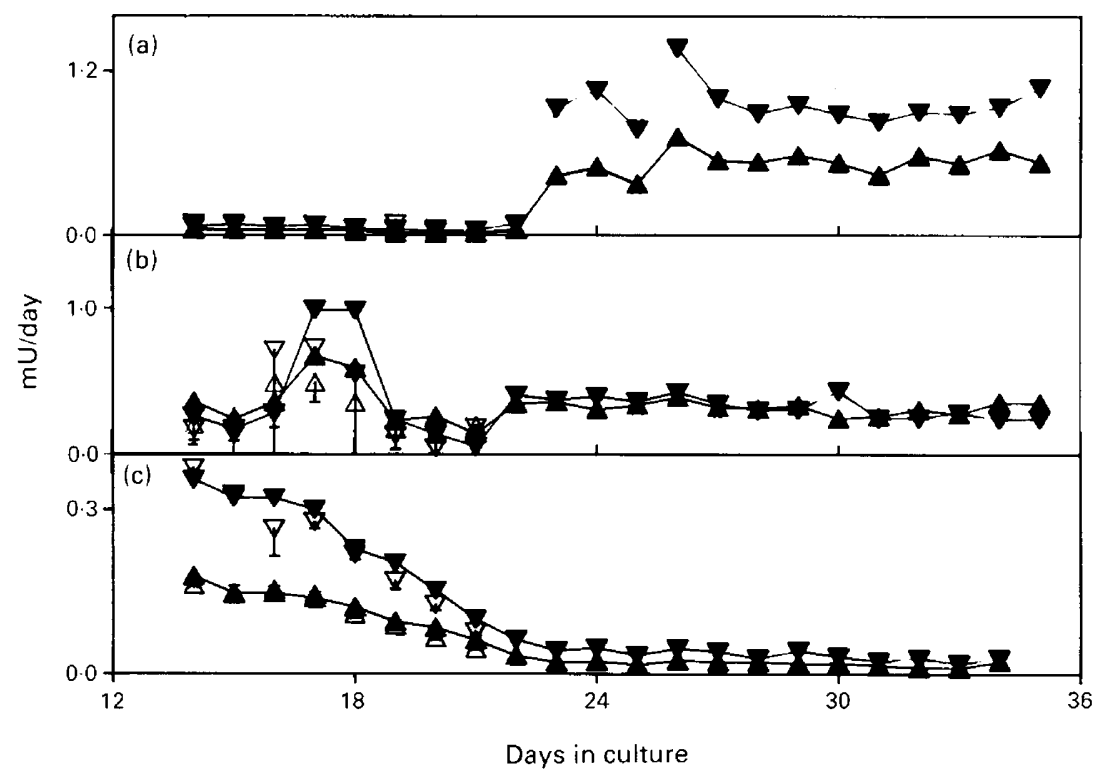

Fig. 10. Secretion of (a) acid phosphatase (ACP), (b) $\beta-N$-acetylglucosaminidase (NAG) and (c) alkaline phosphatase (AKP) by epithelial monolayers derived from the human epididymis (H30). Daily secretion (ordinate) is plotted against time in culture (abscissa) for apically directed $(\triangle, \boldsymbol{\Delta})$ and basally directed $(\boldsymbol{\nabla}, \nabla)$ secretions. Data from one chamber are given by the closed symbols; the mean (and s.e.m.) secretion of 6 other chambers from the same tissue for Days 14-21 are given by the open symbols. 
the monolayers formed; the cells of the monolayer had all the organelles expected of epididymal principal cells. In these respects the cultures resembled those from the rat when cultured similarly (Cooper et al., 1989). As also found in rat cultures (Yeung et al., 1989a), the cells were shorter than those found in the epithelium from which the fragments were obtained or corpus epithelial cells grown in tubule culture (Tezón \& Blaquier, 1981).

Human epididymal cells in culture maintained their lateral interdigitating junctions and apical occluding junctions with neighbouring cells to form the monolayer. HRP provided basally did not penetrate occluding junctions between the cells. The cells were also shown to be active with respect to endocytosis of fluid-phase markers peroxidase (from the apical and basal surfaces) and native ferritin (from the apical). As exclusion of HRP from tight junctions and its uptake from the basolateral membrane into vesicles, multivesicular bodies and lysosomes of principal cells have been observed in short term incubations of intact human epididymal tubules from the same source (Yeung et al., 1989b), the present results indicate that this activity is maintained in the present culture conditions. The cells secreted into the medium 3 enzymes found in epididymal fluid, alkaline and acid phosphatase and $\mathrm{N}$-acetylglucosaminidase (see Cooper, 1986), but the pattern of activity differed between cultures. Interpretation of these data is complicated by the extent of confluence and the larger volume of medium placed below the filter. Nevertheless, the greater apical secretion of NAG in $\mathrm{H} 27$ is consistent with the observed full cover of the filter. With a complete monolayer the equal activities of AKP in both compartments imply a greater basal secretion. In $\mathrm{H} 30$, by contrast, no directional secretion of NAG was found, consistent with the observed partial cover of the filter which would allow diffusion between compartments. That no consistent pattern of enzyme secretion was observed between cultures may reflect the nature of the material available, but good growth seemed unrelated to the age of the patient or any preceding (short-term) antiandrogen treatment.

In summary, the cell culture method described here has permitted for the first time long term maintenance of cells from the human epididymis. This system should provide information on other aspects of human epididymal function.

This work was supported by the Deutsche Forschungesgemeinschaft Grant Ni 130/11-1. We thank S. Mücke, D. Wenker, T. Burgert, S. Raczek, K. Nurmik and C. Bücker for invaluable help with the cultures and assays; and Professor Wittkowski of the Anatomy Department for permitting the use of the Philips 300 electron microscope.

\section{References}

Byers, S.W., Musto, N.A. \& Dym, M. (1985) Culture of ciliated and nonciliated cells from rat ductuli efferentes. J. Androl. 6, 271-278.

Byers, S.W., Hadley, M.A., Djakiew, D. \& Dym, M. (1986) Growth and characterization of polarized monolayers of epididymal epithelial cells and Sertoli cells in dual environment culture chambers. J. Androl. 7, 59-68.

Cooper, T.G. (1986) The Epididymis, Sperm Maturation and Fertilisation. Springer Verlag, Heidelberg.

Cooper, T.G., Yeung, C.H. \& Meyer, R. (1989) Immature rat epididymal epithelial cells grown in static primary monolayer culture on permeable supports. I. Vectorial secretion. Cell Tissue Res. 256, 567-572.

Cutbbert, A.W. \& Wong, P.Y.D. (1986) Electrogenic anion secretion in cultured rat epididymal epithelium. J. Physiol., Lond. 378, 335-345.

Gilbert, S.F. \& Migeon, B.R. (1975) D-valine as a selective agent for normal human and rodent epithelial cells in culture. Cell 5, 11-17.

Harris, A. \& Coleman, L. (1989) Ductal epithelial cells cultured from human foetal epididymis and vas deferens: relevant to sterility in cystic fibrosis. $J$. Cell Sci. 92, 687-690.

Lopez, M.L. \& Breucker, H. (1986) Ultrastructure of the lamina propria of the human ductuli efferentes and ductus epididymidis. Andrologia 18, 147-151.

Tezón, J.G. \& Blaquier, J.A. (1981) The organ culture of human epididymal tubules and their response to androgens. Molec. cell. Endocr. 21, 233-242.

Yeung, C.H., Cooper, T.G. \& Meyer, R. (1989a) Immature rat epididymal epithelial cells grown in static primary monolayer culture on permeable supports. II. Histochemistry and ultrastructure. Cell Tissue Res. 256, 573-580.

Yeung, C.H., Cooper, T.G., Weinbauer, G.F., Bergmann, M., Kleinhans, G., Schulze, H. \& Nieschlag, E. (1989b) Fluid-phase transcytosis in the primate epididymis in vitro and in vivo. Int. J. Androl. 12, 384-394. 